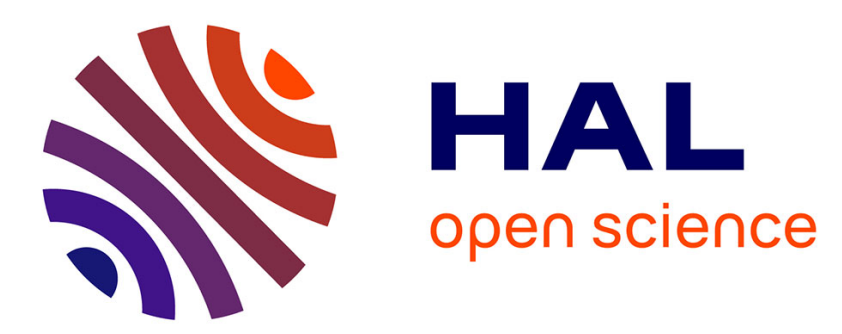

\title{
Education as Construction of Gender Roles in the Greek Novels
}

Sophie Lalanne

\section{To cite this version:}

Sophie Lalanne. Education as Construction of Gender Roles in the Greek Novels. E. P. Cueva et S. N. Byrne éd., A companion to the Ancient Novel, Malden (MA), Oxford, Wiley-Blackwell, p. 473-489, 2014. hal-01981762

\section{HAL Id: hal-01981762 https://hal.science/hal-01981762}

Submitted on 15 Jan 2019

HAL is a multi-disciplinary open access archive for the deposit and dissemination of scientific research documents, whether they are published or not. The documents may come from teaching and research institutions in France or abroad, or from public or private research centers.
L'archive ouverte pluridisciplinaire HAL, est destinée au dépôt et à la diffusion de documents scientifiques de niveau recherche, publiés ou non, émanant des établissements d'enseignement et de recherche français ou étrangers, des laboratoires publics ou privés. 


\title{
CHAPTER 30
}

\section{Education as Construction of Gender Roles in the Greek Novels ${ }^{1}$}

\author{
Sophie Lalanne
}

"[Callirhoe] quickly recovered from the birth and grew stronger and bigger, no longer a girl (kore), but now a mature woman (gunaikos akmen proslabousa)."

(Chariton, Callirhoé, 3.8.3)

Nobody would deny the fact that, to some extent, the five complete Greek novels that have survived through the ages belong to the genre of the "éducation sentimentale" or "Bildungsroman." First confined to a supposedly young and uncultivated public (Perry $1967,175)$, they have proved their ability to reach a high level of scholarly and rhetorical technique (Hunter 1983, 59-83; Bowie 1985, 67-91; Hunter 1994, 1055-1086; Morgan 2004, 5-6) without losing their deep insight on the world of youth. For youth has to be moved from one territory to another: if the audience of the Greek novel was not mainly composed of young men and women to whom the art of love had to be taught, youth and education had nevertheless a great importance in the eyes of the Greek novelists, rhetors, and sophists, who wrote the novels.

The age range of heroes and heroines in particular deserves a special attention 14 and 15 years for Anthia and Habrocomes at the beginning of the novel, 13 and 15 years for Chloe and Daphnis, 19 years for Cleitophon and probably the same age for Leucippe, and 17 years for Theagenes and Charicleia (Lalanne 2006, 73-74). Chaireas and Callirhoe, who are described as meirakion and kore, are probably the same age as Habrocomes and Anthia. Few literary genres put heroes so young on stage except epics: Theseus and Telemachos are, respectively, 16 and 17 years of age when they accomplish their initiation.

Of course, youth plays a dynamic role in the plot itself. Because it implies vulnerability, power of seduction, as well as innocence, it can be seen as a driving force in the meandering stream of the narration. This goes not only for the five complete novels, but, as 
far as we can say, for some of the fragmentary novels that have been preserved, such as Ninos (fr. A2-A3). However, the status of youth in the Greek novels is related also to an original way of looking at society. From Homer to Menander, through Hesiod, Thucydides, Aristotle, or Isocrates, we know that opposition between generations, and especially between young and mature men, gave shape to Greek society (cf. Roussel 1951), and that the increasingly demanding aspirations of each new generation were debated among philosophers and politicians, at least in democratic Athens. What draws our attention is the fact that Greek novelists persist over time, even after the normalization of the Hellenistic age, unless we recognize here an Augustan influence (Néraudeau 1979, 368-383).

This research owes to different trends of French historiography focusing on three different subjects: first, education, in continuity of History of Education in Antiquity, published by Henri-Irénée Marrou in 1948 and recently renewed (Too 2001; Pailler and Payen 2004); then, rites of passage in the way Pierre Vidal-Naquet pursued the work of Arnold van Gennep (for a complete survey, see Vernant and Vidal-Naquet 1992); and lastly, "genre" as the construction of social and cultural gender identities (Sebillotte and Ernoult 2007, introduction, 11-26; Zaidman and Schmitt Pantel 2007, 27-48). The connection between those three independent themes will lead us to examine how a Greek man and a Greek woman were shaped and raised to young adulthood. The Greek novels offer a remarkable field of observation: qualities and abilities are set up in order to draw an accurate portrait of Greek aristocracy, to build a model for all Greeks, and even non-Greeks, in a world where Greek culture is still predominant. I will follow this triptych display, beginning with youth and education, going on to rites of passage, and finishing with gender roles.

\section{Forever Young}

Idealized youth is one of the major features of the Greek novels: after beauty and engeneia, youth is an important part of the heroes' and heroines' identity. Yet, it is far from being an everlasting or timeless quality. The novels focus upon the transformation of the main characters, and a sort of diachronic portrait of each hero or heroine can be drawn (see Lalanne 2006 and 2010). Specific attention is paid to youth and, broadly speaking, to age ranges.

As a matter of fact, all characters display a common set of ages (Lalanne 2006, 66-97), with some variations from one novel to another. Most of the time, when the novelists introduce a new character, they find a way to mention his or her age group. For instance, Chariton often uses the expression $\bar{o} s$ anèr, "as a man who...," as if age and gender explained the characters' motivations, emotions, and actions. Heliodorus uses a large number of periphrases to describe the periods of the life cycle and pays great attention to the question of age. A child, for instance, can be called pais or korē, but also paidion, korion, paidarion, or a group of children can be characterized as paidaria anēba (10.8.1). On the other hand, peoples of Delphi, Memphis, and Syene gather dia pasèse èlikias, "all ages confounded" (7.8.3; 9.11.4; 9.22.1). Heliodorus even adds the criterion of gender to suggest the solidarity of all categories during the siege of Syene: "No one was idle: women, children, and old men alike all joined in the work, for mortal danger is no 
respecter of age or sex" (9.3.8) (English translations are from Reardon's 1989 collection, in which Morgan translates Heliodorus). On the contrary, when nothing is said about ages, it can be deduced that the character is an adult. Only a few characters remain problematic from this point of view: Moeris, Rhenaea, and, above all, Manto. They all appear in the Ephesiaca.

The society of the Greek novels is divided into categories according to the criteria of age and gender, and each novelist builds his own vision of society. For instance, Xenophon of Ephesus and Longus give a well-balanced survey of Greek society, where all groups are put on an even footing, while Achilles Tatius focuses on two categories, young people and adults, and, in doing so, depicts Greek society as the field of an antagonistic relationship between them. However, whatever outlook they give on Greek society, the novelists put a major stress on the age of education and socialization.

Two different measures are used for men and women in the Greek novels. For men, six age groups appear: pais (child), meirakion (adolescent), neaniskos (very young man), neanias/neos (young man), anēr (man), and presbutēs (old man). This list of terms is the result of the connections between a traditional description of ages (pais, ephebos, neos, anēr, gerōn) and the frequent use of meirakion and neaniskos as developments of ephebos in comedy and medicine (Golden 1990, 12-15; Lalanne 2006, 70-71). Even if it is often difficult to make a clear difference between a neaniskos and a neanias, for instance, it is obvious that these categories form a common reference at the time of novels' composition and cover a small number of years in a man's life.

The age-scale for women is less detailed, especially when youth is concerned: the woman is first a pais (child), then a kore (girl), a gunē (woman), and, at last, a presbutis/ graus (old woman). The kore has usually reached the age of puberty, but not always (e.g. Charicleia); she is often a virgin, but she can be married too. The gune is generally a married woman. The general consensus of those who look carefully at this aspect of characterization is that the novelists make great efforts, in spite of the usual anthropological simplicity of women's age scales, to balance the situation of women with that of men. Thus, the different steps of evolution in the life cycle can be traced for each young character, boy or girl, as seen for Chaireas and Callirhoe (Lalanne 1998, 518-550) and other heroes and heroines.

\section{Education in the Greek Novel}

In the Greek novels, education intensifies gender distinctions. Paideia introduces a strong separation between tasks, qualities, and status, and establishes an imbalance to the benefit of boys, though the beginning of novels tend to show a different situation, as if girls' advantages fall to their lot by nature but were diminished according to a social pattern that keeps in store for future citizens all social prerogatives: political power, public speech, freedom of choice, ability to spend one's fortune, etc. And yet, Greek society rests on the fact that places where education occurs, pedagogical contents, qualities to be gained, as well as the social status that results from all this are determined according to gender.

All heroes belong to the gymnasion of their city, except Daphnis who lives as a slave in the countryside and chooses to remain a country dweller even after his aristocratic status is revealed. Chaireas and Habrocomes, who are the youngest heroes, are said to frequent 
this educational center (Callirhoe 1.1.5; Ephesiaca 1.2.2). Their training is sport, more than military discipline. Chaireas has been taught the kicks of pankration; Cleitophon has been taught the art of riding a horse; Habrocomes is well known for his various talents in hunting, riding a horse, and practicing hoplomachia; Theagenes knows the various techniques for taming a bull. However, this representation of education is silent about a long-known evolution out of ephebeia that leads to the increasing role of intellectual and literary contents (Marrou 1981 [1948], 147) in a political world more and more impregnated with rhetorical technique, as the Second Sophistic's development shows (Gleason 1995). Even if it is obvious on some occasions that the young heroes have been given such a cultural background, it seems that intellectual capacities do not count among the highest qualities required from a young Greek aristocrat. The gymnasion is nothing in the novels but a place for physical training and male sociability.

Unlike heroes, some heroines such as Leucippe and Charicleia, who are accomplished pepaideumenai, are depicted as having received an intellectual and literary education, probably at home, with a private tutor or their own father. Leucippe is indeed a têroumenē parthenos, a "well-guarded virgin" (1.9.3) confined to her room and her uncle's garden where she can read and play the cithara, and has certainly always been treated this way; Charicleia was probably taught by her adoptive father Charicles, Apollo's priest in Delphi, though nothing is said about it; Chloe is given the minimal knowledge a young shepherdess can have and spends a terribly annoying time with her supposed mother who teaches her "how to card wool and turn spindles and going on about marriage" (3.4.5). This radical change in her life immediately precedes her nubility at 13 years of age, and, after acquiring a rudimentary agricultural competence (grazing, observation of nature, making of small objects, grape-harvesting), when her mother teaches her weaving skills that form the main part of feminine activity, this is the end of Chloe's education. At age 15, she is old enough to be married and to become a perfect despoina oikias (the "mistress of a house," 3.25.2). Thus, what makes the difference is not her coming of age, but the social recognition of it during the grape-harvesting time when men and women communities meet each other. Two events have played an important role in this development: the long and harsh winter that prevents peasants from venturing out of their home and the great pastoral feast at which Chloe's rescue by the god Pan is celebrated. All places of education are gender-determined. Religious feasts or visits to temples are typically where young men and young women meet, as these are the only opportunities for girls to go out.

The content of education greatly varies between girls and boys. In the Greek novel, it takes an idealized form in combination with a life of adventure and heroism conceived in an epic pattern for boys, in a mythological scheme for girls (Lalanne 2006, 122-128). In the whole corpus of Greek novels, heroes must leave in search of their beloved, either on their own initiative or at the behest of the heroine's father. Heroines, with the exception of Charicleia, are forced to play a passive role, i.e. to wait for danger and rescue, in spite of their personal qualities. The hero is subjected to an initiation to sexuality, while the young woman must preserve her chastity at any cost. Lastly, the hero must prove his ability to master speech: verbal contests (in trials, for instance), narration of myths, and public orations illustrate the fact that the young man must be a quality speaker. Heroines are not supposed to play this role even if they are depicted as being more clever or witty. Callirhoe, Anthia, Chloe, Leucippe, and, in a more subtle way, 
Charicleia are equally taught to stay silent and obedient toward their kurios and to accept the decisions he will make.

Moral values unify both genders, and the same qualities are expected from boys and girls: courage, self-control, equanimity, piety toward gods and parents, respect for institutions, fidelity, and chastity (even with lapses allowed to young men, and young women too, if married), which may be considered as respect for the institution of marriage. These qualities gather all heroes and heroines under the same ideal of Hellenism based on the excellence of Greek paideia. An opposition between the good qualities of Greeks and the irritability, cupidity, lust, and jealousy of barbaro $i$ is mentioned on several occasions. Masculine and feminine forms of courage differ by their name: while young men are taught andreia, young women are qualified through the notion of arete, since the other term remains too strongly entangled with virility.

The distribution of gender roles that results from the various sequences of initiatory ordeals in the novels confirms what we know about Greek societies. With the exception of Theagenes and Charicleia, where the female clearly dominates, other hero-couples illustrate well a specialization of gender roles, as well as the expected hierarchy between men and women in a patriarchal society. Here, we meet a cultural scheme that Nicole Loraux (1981) has brought to light, drawing a parallel between war and childbirth. A remarkable continuity seems to characterize gender relations in the Greek domestic sphere in spite of major changes in political, social, and cultural environments. Young women are prepared for the "bed," an actual metaphor of sexual relations and motherhood, whatever heroic qualities may be granted to them in the Greek novels and in the contemporary sources as well, like Plutarch's Erotikos. Thus, at the end of the whole process of socialization, the gender gap is deeply engraved in the basis of Greek society.

By the time they return home, heroes and heroines have risen to a new status, as high as their own parents and as high as could be expected from their youth in their city when they were said to be the "first" by birth and beauty. However, the most remarkable aspect of this new status is the normalization of their relationship, which was, at the beginning of the novel, asymmetrical and in favor of girls and young women. To some extent, the final order neutralizes the originality of the girls' initiation, which appears, consequently, as the effect of a novelistic license. At the end of the novels, the reader is offered to contemplate two polished cultural products: a Greek man and a Greek woman.

\section{The First Ordeal: Separation}

In ancient Greek history, youth's social behavior has been analyzed in light of the anthropological notion of "rite of passage," in terms of rituals, marriage, war, and hunting. This notion, outlined by Arnold van Gennep 100 years ago (1909), expresses the idea that each individual successively occupies different social status in the course of his life, and that most human societies set up rituals intended to emphasize the transition from one status to another and to make these transitions more acceptable for the individual. Transitions can be divided into three critical phases (each further divisible): separation, liminality, and incorporation. This scheme finds a remarkable application within the scope of the Greek novel. 
Separation is probably the most impressive of the three phases. Parents are more affected by the stage of separation than they perceive as they realize they will never recover the child they are letting go: even if he comes back, he will never be the same. In the Greek novels, which exemplify the organization of a patriarchal society, fathers play a prominent role. Unlike most societies, separation has to be made primarily with fathers instead of mothers. The fathers of Anthia and Habrocomes are the ones who decide to make the just-married couple travel by sea (1.10.3); in Daphnis and Chloe, both fathers, Dryas and Lamon, who discovered the exposed infants (1.2 and 1.4.5), dream that Eros ordered Daphnis to be made a goatherd and Chloe a shepherdess (1.7.1-2), and they send their children to wander over the fields (1.8.1-2). In Chariton's novel, Callirhoe's father, Hermocrates, leads the procession that conveys his daughter to her tomb (1.6.3), and in the Aethiopica, Charicles convenes the Delphian citizens' assembly and, through imprecations, convinces them to pursue the kidnappers of his adopted daughter (4.19-21). In each example, the father embodies both authority and affection and overshadows the mother's character.

In order to make the child's separation from the parents more spectacular and more active, this stage is ritualized: oracles and dreams are interpreted as expressions of the gods' will. Apollo, whose oracle in Colophon is consulted by the fathers of Habrocomes and Anthia, decides the young couple's fate (1.6.1-2). In the Aethiopica, Apollo determines, through the Pythia's voice (2.35.4-5), what will happen to Theagenes and Charicleia, just after Calasiris, Charicleia's spiritual father, and Charicles, her adoptive father, have dreams that announce the oracle. The first dream, in which Apollo and Artemis order Calasiris to take the two young lovers back to their home city (3.3.5), influences the course of events as it provokes the heroes' departure. The second dream is premonitory: Charicles sees an eagle flying off from Apollo's hands and abducting Charicleia (4.4.12). It prepares the old man for the painful separation. In a dream of the first type, that Dryas and Lamon share in Longus, the Nymphs appear to tell both fathers to entrust Daphnis and Chloe to a winged boy easily identified with Eros (1.7.11.8.2). Dreams underline the role of gods in the separation stage, and the children's departure is celebrated with many prayers and sacrifices.

In Greek novels, with the exception of Daphnis and Chloe, separation takes the form of boarding a ship. Most often, preparations precede the launching, but the rapidity of the heroine's abduction is a surprise for the reader. Both Callirhoe and Charicleia are kidnapped, Callirhoe through her apparent death and abduction by tomb looters (1.5.1; 1.9.7), and Charicleia by her lover (4.17.3-5). Chloe is abducted by the young men of Methymna, a motif that echoes the other novels even if its placement is unusual in the overall frame. As for Leucippe, she elopes with Cleitophon, but Calligone, Cleitophon's half-sister, is kidnapped in her place (3.18.1-5). This abduction of a young woman by a young man is one of the most common forms of separation. In the novels, departure is sudden, painful, and perceived as a major event both by the protagonists and their parents. The novelists stage separation with great care, representing it as a great public ceremony: funerals and a trial in Chariton's novel; a long procession of Ephesians accompanying Habrocomes and Anthia to the harbor in Xenophon; and the gathering of all Delphians giving chase to the Thessalians in Heliodorus. The crossing of the sea is the true moment of separation. During this travel, disturbed by pirates, tempests, and 
shipwrecks, the heroes are maintained in an interspace, a sort of liminal period preceding the liminal stage proper.

The leaders of pirates or brigands in these novels are intimately associated with the travel theme and introduce the idea of the hostility of the world that the young heroes are about to discover at the borders of Hellenized territories. These chiefs are either banished or marginalized rebels and represent transgressive figures to which heroes could conform themselves if they were not so obedient to the gods. As the heroes leave their parents, who, judging by their response to the dreams the gods send them, are obvious models of piety, they meet, in the course of their journey, various characters that illustrate values opposite to chastity, piety, and moderation (e.g. Hipothoos or Thyamis). These meetings that occur immediately after the stage of separation confront the heroes with the image of alterity, of a potential but undesirable self. The heroes have to make an active choice how they will live their own lives, having forever left behind them the comforting shores of childhood. As a sign of this necessary loss, it happens that close secondary characters die at this stage of the novel, for example Habrocomes' old servant, or Dorcon, Daphnis' rival.

The disappearance of the ship that conveys the heroes to a new and hostile world is important to the separation's ritual. In Callirhoe, the ship that Hermocrates offered to Chaireas to bring his daughter back to Syracuse is burned by Phocas, the steward of Dionysios' estate (3.7.1-3). In Leucippe and Cleitophon, a dreadful tempest destroys the ship and only spares the prow, the mast, and the yard (3.4.3-6). In the Aethiopica, after a terrible shipwreck, the ship is looted and abandoned along a beach where brigands begin to fight furiously; the novel opens with the spectacle of the empty ship and the pathetic remains of a banquet gathering dead and wounded bodies (1.1.2-7). This serves not only as a manifestation of the young heroes' divine beauty, which Heliodorus stresses, but also of their desperate isolation. In the Ephesiaca, pirates attack the just-married couple and burn their ship, heavily loaded with riches and slaves (1.14.1-3). The Ephesiaca is probably the best example of this ritual of separation, for it illustrates all the elements already mentioned (1.10.4-11.1), many of which suggest the idea that the heroes have to renounce the past and break the ties that closely link them to the persons and objects from their childhood. This separation takes place under the supervision of two kourotrophoi divinities, Artemis and Apollo.

\section{Continuing against All Odds: The Liminal Stage}

Once the ship that conveyed the young heroes over the Mediterranean has disappeared, they are completely lonely and without resource. They are now bound to wander along the borders of the Greek-speaking world (for Daphnis and Chloe, beyond Dionysophanes' estate, 200 stadia, or 23 miles from Mytilene). This situation is not meant to be permanent. It allows the heroes to become more mature and have their personalities transformed. This is how van Gennep (1960 [1909], 17-18) defines the second phase of a rite of passage: "Quiconque passe de l'un à l'autre [des deux territoires] se trouve ainsi matériellement et magico-religieusement, pendant un temps plus ou moins long, dans une situation spéciale: il flotte entre deux mondes. C'est cette situation que je désigne du nom de marge." The fragmentary novels of Ninos, Metiochos and Parthenope 
and The Babyloniaca seem to have been based on the same original plot containing a sea trip, a separation between the two young lovers and a long wandering.

Heliodorus is particularly keen on the motif of wandering (ale and planēe. It is striking that, in the latest novels, those of Achilles Tatius and Heliodorus, as the geographical frame of the adventures extends, the feeling of wandering takes on a more and more important place. Chariton refers to this notion in a different way: Callirhoe mentions from time to time the border beyond which she does not want to pass, first the Aegean sea, later on the Euphrates river, but she seems to be bound to an ever-more-remote destination.

As a matter of fact, in the Greek novels, the heroes are bound to the four points of the compass, following the lines of the oikoumene, the civilized world according to the Greeks of the classical period: Magna Graecia in the west, Byzantium and Cappadocia in the north, Babylonia in the east, and Aethiopia in the south. These lands are the eschatiai of the heroes' adventures, these inhospitable edges that mark the end of well-known territories (Robert 1960). Ep'eschatois horois is the expression Heliodorus uses in the famous scene of Aegyptian necromancy, when a dead man reveals Charicleia's future (6.15.4). Eschatiai respond to their most accurate definition in Daphnis and Chloe, where they are limited by the city's borders and which are described as a wild countryside, where only shepherds and goatherds are found. Daphnis and Chloe do not suffer exile, but left on their own every day in the fields, they endure ordeals that are not different from heroes in other novels. Wandering suggests more than exile, isolation, and vulnerability: it is attached to the fury of an unfavorable fate, to the heartache of departing from one's native city, to the distance from one's parents, to the inversion of status that turns proud aristocrats into outcasts, and, last but not least, to the desire for return. All of these themes are common features of an initiatory path.

The sea trip may be specific to Greek initiations, for Greeks used to have an ambiguous relation with the sea, a source of attraction and repulsion (André and Baslez 1993, 11-42). In the Greek novels, it is certainly the most dangerous place, where one encounters tempests, shipwrecks, and pirates. Callirhoe keeps repeating the idea that the sea is an obstacle between her parents, her city, her husband, and herself (e.g. 3.10.8; 8.4.10). In Xenophon (1.6.2) as well as in Heliodorus (6.15.4), the sea trip is announced by an oracle as the decisive stage of the heroes' initiation. In Greek representations since Homer, the sea is perceived as moving and precarious, a metaphor of life itself. In the novels, misfortunes are often compared to unforeseen events of navigation. Through sailing, novel heroes are connected to their heroic predecessors such as Odysseus, Telemachus, Theseus, Jason, even Paris (Duchêne 1992). Greek heroes not only have to win various trials, but also have to roam the seven seas to accomplish their initiation. Even Daphnis and Chloe, the most pastoral of the five complete novels, takes place on the island of Lesbos, which leaves space for various events related to the sea, such as Daphnis' abduction by Tyrian pirates (1.28-31), Chloe's kidnapping by young Methymnians, and her rescue by Pan (2.19-28); the noise of a small fishing boat, which leads to the narration of Echo's myth (3.21-23); and Daphnis' discovery of a purse containing 3,000 drachmas on a beach next to a dolphin's corpse (2.27). When Daphnis discovers Chloe bathing naked at the beginning of the novel, Longus writes: "The bath seemed more terrible than the sea. He thought he must have left his life behind with the pirates-for he was young and a country boy and still ignorant of the piracy of love" 
(1.32.4). The sea is an inescapable locus in Greek initiation and Longus plays with it, recognizing its key role.

Facing death is another compulsory stage of a rite of passage, especially in the passage from childhood to adulthood, as van Gennep underlined. Heroes of the Greek novel are often threatened with a most terrible death, enduring not only shipwrecks, fires, and battles, but also personal ordeals, for example Anthia is bound to a tree and sacrificed to Ares; Leucippe's head is cut off and her body thrown overboard; Daphnis falls into a pit; Theagenes is severely injured by pirates; and Callirhoe and Anthia are buried alive. These cases of fictitious death are perceived by the characters themselves and by the reader as a journey through hell. In some novels (e.g. the Ephesiaca), corpses of characters too young to die are strewn on the ground, many of whom stand in for the heroes (mythological characters for heroines, and "Patroclus" figures for heroes) and disappear before the end of the novel, often hit by a violent fate: Phatta, Echo, Syrinx, Pitys, Dorcon, Hyperanthes, Anchialos, Charicles, and Chaireas. Suicide is another aspect of omnipresence of death, as well as the motif of seclusion in a cavern, a sacred cave, a pit, a hut, a jail, or an empty grave-even the sea is compared to a grave (e.g. Leucippe and Cleitophon, 5.16.1). These isolated places allow the youth to stand apart from the world during a definite period and to regress to an original stage before going through a second birth.

However, a rite of passage cannot be qualified as such if the liminal stage was not based on the pattern of inversion. This reversal is essentially an inversion of social status. Heroes and heroines feel cut off from the world of the Greek cities by the surface of the sea and remote lands; they feel lonely and helpless and, reduced to captivity, they are submitted to repeated sexual assaults. No one expresses this forfeiture better than Callirhoe, who is at the same time the proudest of all these young Greek aristocrats, sons and daughters of the first citizens in their city, when she describes herself as doule kai xenē, "a slave and a foreigner" (2.5.7). This pair of ideas expresses the exact opposite to what lies at the basis of high social status: being free, being a citizen (or a citizen's daughter), and being a Greek aristocrat. Inversions of gender, if not uncommon, are not important features. Leucippe, as a slave, has her hair shaved and is "turned into an ephebe" (5.19.2); Cleitophon takes Melite's garments to disguise himself and escape Thersander's watchfulness (6.1.3); and Chloe wears Daphnis' clothes for fun (1.24.2). Most of these transformations are anecdotal (except for Leucippe, eventually) and appear to reinforce the general feeling of the reader that, for a certain length of time, and until the final reversal, life is upside down.

\section{A Time for Return: The Incorporation}

The long succession of ordeals that befall the young heroes must come to an end with the sudden vision of their mother city or, to be more precise, of their father city. In Callirboe, the Ephesiaca, and Leucippe and Cleitophon, the rite of incorporation takes the form of a triumphant return on a ship. The heroes and heroines are warmly welcomed and take a new place in society, as members of another restricted societal subgroup demarcated by age, sex, civic, and social status. Young men enter the men's community (andres), while young women are introduced into the group of married women (gunaikes). This is the final stage of a long process of maturation through the various 
events of the novels. And these two communities of andres and gunaikes precisely come onto the pier to celebrate the return of the heroes.

When the heroes are not married at this stage of the novel, the end of the narration focuses on their wedding. While Achilles Tatius discreetly alludes to Leucippe and Cleitophon's marriage (8.19.2), Longus and Heliodorus describe in detail the preparation for the wedding festivities. Longus even concludes his novel on the wedding night (4.40.1-3). Heliodorus makes a public event of the transmission to Theagenes and Charicleia of the symbols of the priesthood that they acceed to when getting married. The couple appears on a chariot bound for Meroe with Hydaspes, the king of Aethiopia, and the queen Persinna on board, as well as the first of Gymnosophists, Sisimithres, and the priest of Delphi, Charicles, in the middle of acclamations, applause, and dances (10.41.1-3). In both novels, this ceremony sanctions the integration of the young couple into their proper social category. It follows the recognition of the heroes by their natural parents, which is a form of reinforcement of the incorporation's ritual. It contains in itself the idea of return, not to a homeland but to an original family, since the heroes are offered to assume their place in a line of descent, and, what is more, in an aristocratic lineage. See, for example, the recognition of Daphnis: every detail reminds us of a family reunion and Daphnis puts on "expensive clothes" (4.23.2) that better suit his new social status and that he wears as naturally as he grazed his goats. Putting on the costume of a citizen is the equivalent here to taking up arms: a visible sign of incorporation into the men's community. The fact is underlined by Daphnis sitting next to his natural father (4.23.2).

In each of these situations - return, marriage, or recognition-the incorporation stage responds to the separation stage. Slight variations may be observed but they do not hide the symmetrical conception of structures. The heroes are welcomed with a ceremony that is a reversed repetition of the one they endured when they departed from their city.

Religious ceremonies stress the various stages of this "return." The last book of Daphnis and Chloe, for instance, abounds in sacrifices and banquets: when Dionysophanes recognizes Daphnis as his son (twice, 4.25.2; 4.26.1), when Daphnis and Chloe get engaged (4.32.3), when Dionysophanes tries to find Chloe's natural parents in Mytilene (4.34.2), and, at the very end, at Dionysophanes' villa, at the final wedding (4.38.1). In Callirhoe (8.8.15), Leucippe and Cleitophon (8.19.3), the Ephesiaca (5.15.2), and the Aethiopica (10.41.1-3), the heroes are celebrated with various feasts and rituals, most of the time as thanksgiving offerings to the gods at the end of their tribulations. As a symmetrical feature to their departure, their parents are most often present. In Callirhoe, as soon as they hear about their children's return, Hermocrates and Ariston rush to the harbor to meet them (8.6.10). Later, Hermocrates introduces them to the theater to offer a public narration of their adventures. This presence of parental figures adds solemnity to the reintegration of the young heroes. In the Ephesiaca, the four parents are already deceased, but Habrocomes and Anthia climb to the top of the city of Ephesus and, after having accomplished sacrifices to Artemis, erect a monumental grave (5.15.2). This action marks their nobility as well as their filial piety. In Daphnis and Chloe, as well as in the Aethiopica, all parents gather for the final scene. When Daphnis and Chloe get married, Lamon and Myrtale, Dryas and Nape, Dionysophanes and Cleariste, Megacles and Rhode all attend the banquet (4.37-38). During Charicleia's and Theagenes's enthronement, Hydaspes and Persinna, Charicles and Sisimithres (representing the deceased and 
lamented Calasiris) take part in the ceremony (10.41.1-3). Theagenes' parents are never mentioned in the novel.

Young heroes are not anymore considered as adolescents (korai, neaniskoi, neaniai) whose beauty is essentially the expression of their family's nobility, social status, and high education, but as adults who are naturally bound to succeed their parents. The accomplishment of fearful ordeals legitimates their belonging to a lineage and allows them to take the place of their parents. In the Ephesiaca, the two old couples of parents bequeath their fortune and social rank to Habrocomes and Anthia (5.15.3), while Leuco and Rhode inherit from the old man of Xanthos (5.10.11) and Hippothoos from his old wife (5.9.1). In this novel, the generation's renewal works remarkably well, but the same scenario can be observed in all novels.

As a conclusion, the Greek novels illustrate, more than any other type of historical source, the education and socialization of Greek youth, women included. What makes this analysis particularly interesting is, first, the extraordinary cultural continuity in which Greeks conceived the best possible education and training, and, in second place, the actual construction of gender roles in Greek society.

\section{Let's Make a Man of Him!}

Andreia is first and foremost a masculine quality. The etymology of the notion implies that it is a part of men's identity and excludes girls and women de facto. Yet, Plato himself, in the Laches and the Protagoras, emphasizes the fact that andreia is produced by education (see Rosen and Sluiter 2003, introduction). It is not only a matter of physical strength and self-confidence but also of wisdom and knowledge, implying the construction of a social and cultural identity. Thus, girls and women are not essentially deprived of any sort of courage, but andreia participates in a specific system of representations. Greek novels deal with this necessary education of young men.

The term andreia appears in several novels, along with andreios, but it is best illustrated in the character of Chaireas, once a ship commander. Only Dionysios (5.9.8), Chaireas $(7.2 .4 ; 7.5 .11 ; 7.6 .7)$, his 300 soldiers $(8.8 .13)$, and the Tyrians (7.2.7) are qualified with such terms. Except for Dionysios, for whom it may evoke moral strength, andreia belongs to the vocabulary of war. When Polycharmes convinces Chaireas to look for death on the battlefield instead of committing suicide, he refers to the heroic dimension of andreia, implying dignity and glory: "It would be a noble thing to do him so much harm that he really regrets his actions, and to leave behind for future generations a glorious tale of how two Greeks who were unjustly treated paid out the Great King by the suffering they caused him, and died like men" (7.1.8). Chaireas uses this plea for himself when he explains later to the Pharaoh why he and Polycharmes should go over to the enemy's camp (7.2.4). The acquisition of andreia will be accomplished when Chaireas chooses in the Pharaoh's army the men he will command and when he is cheered and elected as their strategos. After he takes the cities of Tyr and Arados, he is at last recognized as andreios (7.6.7).

In Heliodorus' novel, andreia mainly characterizes the hero. Along with beauty (3.3.8), and in opposition with Cnemon's cowardice (2.7.3 and 2.18.4), it inspires respect and admiration and is considered as a divine quality (10.28.4). Besides, 
Hydaspes' andreia merges into the virtues of a king, that is, of a formidable and magnanimous warrior: he "has the capacity to destroy his enemies utterly but is naturally inclined to take pity on suppliants" (9.6.2). War is obviously what makes valuable the masculine and "civilized" (i.e. Hellenized) form of courage. To Hydaspes' bravery are contrasted Oroondates' disgraceful flight from the battlefield (9.19.1) and the harshness of the king of Persia whose "rigor in punishing any who show themselves cowards in war tends to exceed his generosity in honoring the brave" (9.21.4). Thus, Hydaspes' andreia is offered as a model to Theagenes who will probably succeed to him on Ethiopia's throne.

As for Achilles Tatius, andreia is nothing but a manifestation of male sexual power, through the verb andrizesthai, which means "to accomplish sexual performance" (2.10.1; 4.1.2). The novelist deals with this subject as he always does, with humor: andreia and andreios never qualify Cleitophon himself but the god Eros stringing his bow $(2.4 .5 ; 2.5 .1)$, the boastful mosquito in Satyros' tale $(2.22 .3)$, and the gymnasion's comrades of whom Thersandros is accused to have been the eromenos in the insulting prosecution speech pronounced by the priest of Artemis (8.9.4). When andreia is normally associated with war, it is a way of denigrating the barbaroi's cowardice (4.14.9) or to build around the character of Callisthenes the ideal of male accomplishment on the battlefield (8.17.9). Thus, while Daphnis' masculinity grows and expands on the basis of a metaphoric triptych composed with panpipes, the art of shepherd and sexual performances, Cleitophon, as a typical "chasseur noir," is torn between his sexual instincts and a restraining system of social norms that he obstinately refuses, standing permanently half-way between the savage world of his sexual fantasies and the world of the city where he is probably expected to become a strategos (see Lalanne 2006, 192-204 for Daphnis; 168-174 for Cleitophon).

Thus, masculinity has to be taught. As a matter of fact, male identity is composed of a set of well-defined qualities that have to be achieved and constructed, though most of them can (must?) appear as natural. In order to make a man of the novel's hero, there is need first of an agonistic context, then of strong men's solidarity. In the novels, the agōn takes place in three main areas: war, gymnasion activities, and oratory, three areas recognized as playing an important role in the construction of Greek masculinity (for war and masculinity, see Loraux 1982; Vernant 1982 and 1989; for sports, see van Nijf 2003; for rhetoric, see Gleason 1995). Then the acquisition of andreia by the novels' heroes becomes a common matter in which a large number of characters are involved, all of whom are men. Every character of the Greek novel has a particular position in society, within an age group, a gender-based community, a social or political organization, and men play a predominant role in this society. Many of them have a part in young men's education, by stimulating their taste for competition, provoking them, encouraging them, protecting them, giving pieces of advice especially in love affairs, and welcoming them in the society of male adults. There is no equivalent form of solidarity among women in the Greek novel. Some of the masculine assistants of the heroes are either initiators (Philetas for Daphnis; Aigialeus for Habrocomes; Calasiris for Theagenes; eventually, the Pharaoh for Chaireas) or most faithful friends (Polycharmos for Chaireas; Hippothoos for Habrocomes; Clinias, Menelas, and Satyros for Cleitophon; Cnemon and, on some occasions, Thyamis for Theagenes). Men's friendship appears as a fundamental component of social structure (Konstan 1999, especially 6-7), but 
two other male figures play their part: the hero's father and, even more often, the heroine's father who supports his (future) son-in-law better than his own daughterHermocrates illustrates well this paradox.

Thus, everything is done to help the young men achieve their education in the best conditions, and most of the men take part in this process because it forms the basis of the whole society. Urged to become men, supported to do their best (even if the results can be deceiving), sometimes even pushed against their will, the heroes of the Greek novel often appear to be the reluctant victims of education. Masculinity may almost be considered as a constraint and a burden.

\section{But What Is a Greek Woman?}

At the beginning of the novels, not only do heroines occupy a higher social position than their male counterparts (Callirhoe, Charicleia), but they are also presented in a more prestigious way (Callirhoe, Anthia), and show more maturity (Callirhoe, Chloe) and intelligence (Chloe, Charicleia). Leucippe is a gifted parthenos: she reveals her talents as a learned and eloquent young woman $(2.6 .2-3 ; 5.18 .2-6)$, and shows herself even more competent in mythology than Cleitophon (2.6.3). It even happens that Callirhoe goes above her social role by giving strategic advice to Chaireas as to how to command the soldiers and prisoners whom he holds on Arados (8.2.4). Yet, the accomplishment of ordeals of these women leads to an unsurprising reversal: they are being taught the importance of chastity; obedience to their husband; piety toward gods, their parents, and their city; and they learn how to become philoteknoi and philandroi, as Plutarch puts it (769 B, $769 \mathrm{D})$. In spite of all their obvious qualities, young women are moved down to second place.

The heroines acquire a feminine aretē by themselves, through terrible ordeals full of cruelty and self-indulgence from both the writer and the reader. They cannot rely on any sort of gender solidarity that could be compared to men's support groups, except on very special occasions, for example Charicleia from the queen Persinna or Anthia from the slave Rhode. Yet, the novelists have invented a special support for their heroines which connects them to the most remote epic heroes: the goddesses, whose number is superior to that of gods, pay special attention to them. The heroines are first protected by Artemis as a kourotrophos divinity and then move to another sort of protection, the protection given by Aphrodite and other goddesses of marriage, maturity, and fertility such as Isis, Astarte, the three Nymphs, and Selene. Heroines are compared to Artemis on several occasions, especially Callirhoe (1.1.16; 6.4.6), Anthia (1.2.6-7), and Charicleia $(3.4 .2 ; 3.4 .5-6)$; a great part of Leucippe and Cleitophon also takes place in Ephesus, and Artemis plays an important role as an initiatory and protective divinity in Achilles Tatius' novel. Aphrodite plays a major role in Callirhoe, first because the heroine is constantly compared to her, then because she never misses an opportunity to pray to the goddess in her temples or altars. In Leucippe and Cleitophon, Aphrodite shows a double face: she embodies the "pleasures" and "mysteries" attached to her name (4.1.6-7), but she also presides over marriage $(2.11 .2-4 ; 5.16 .4)$. The goddess never takes another appearance than the Greek one but she is assisted by oriental divinities of love and fertility like Astarte, Isis, and Selene. The protection of Astarte is only suggested in Leucippe and Cleitophon (1.1.2; 2.11.4), but Isis, whose cult is widely 
spread over the Roman Empire, protects Anthia who invokes her as the "greatest of goddesses" (4.3.3), and Selene is mentioned in regard to Leucippe (1.4.3) and Charicleia (10.41.3), especially through the symbolism of the torch. The evolution from Artemis, protector of girls, to the goddesses of marriage and fertility, is at the basis of the characters' evolution itself.

While the heroes had to go in search of their beloved and face ordeals of action such as fighting, competing in oratory speech, and taming bulls, heroines must reveal their qualities through passivity, silence, acceptance, and preservation of their chastity. It is clear that the virtues that are expected from them essentially refer to married life: chastity, hope, silence-all virtues that make women invisible (cf. Eur., Herakl., 476-479; Soph., Ajax, 292; Thuc. 2.45.2). What Winkler (1981) wrote concerning certain events in Chloe's initiation must be extended to the whole novel, and to all heroines of the Greek novels. The gradual receding of the heroines, with the notable exception of Charicleia, responds to the personal development of the heroes. Both phenomena are so interconnected than they deserve a parallel study (Lalanne 2007).

However, this is no epic matter. Novelists only write love and adventure stories about their heroines and deny them the privilege of glory. Even Charicleia, whose name suggests renown, is praised for her beauty (2.35.5): "hers is the great reputation whose fame, whether for excellence or blame, is spread least among the males" (Thuc. 2.45.2). In spite of all appearance of symmetry, the Greek novels lead to the same conclusion, which is that the female spouse must occupy a second place, whatever qualities may be attached to her. The Phatta tale in Daphnis and Chloe (1.27.1-4) can be interpreted as a warning to women who would compete with men. Many years after Xenophon's Oeconomicus, the heroines of the Greek novels are not so different from the unnamed young spouse that Socrates helped Ischomachos to educate (Schmitt Pantel 1994-1995).

Finally, the most remarkable heroines are Callirhoe and Charicleia, who differ from other heroines in having a strong personality and a vigorous aretē and who outclass their lovers with well-established social superiority. The fact that Chariton devotes the first and last paragraphs of his novel to his heroine, Callirhoe, specifying that he intends to tell her story and no other one, deserves special mention. Charicleia too is an exception through her intelligence and eloquence. Both are self-confident and proud of their origins and education. Nevertheless, a paradoxical reversal results in these two heroines also being the ones who keep the tidiest relationship with their fathers and who are the most evidently submitted to their authority. Through adventures, Callirhoe moves from one kurios to another, father, husband, or master. Hermocrates stays an absolute for his daughter whose first mention is as his daughter (1.1.1) and who never stops invoking $\operatorname{him}(1.14 .10 ; 2.5 .10 ; 5.1 .5 ; 5.5 .4)$. He sends Callirhoe to the temple where she meets Chaireas, he decides to please the people of Syracuse by marrying them together, and he organizes a beautiful funeral when she is thought to be dead. He also sends Chaireas to look for her. As a final example, he welcomes her in Syracuse in a very tender, almost an amorous way (8.6.8) while his wife is not even mentioned, and he seems to give her a second time to Chaireas. Thus, Callirhoe is so overwhelmed by her father's renown that she appears as "the daughter of Hermocrates, whom even the Athenians had not taken" (3.4.18), a young woman who virtually succeeds her father as long as no male heir exists but who has no identity in the family. When one considers that her major ordeal is to give 
birth to a son, one holds a key element in understanding Callirhoe's status of epiklēros (Lalanne 2006, 246-252).

In the same way, Charicleia remains under her father's domination. What makes this fact almost pass unnoticed is the multiplicity of her fathers. Three fathers actually take care of her: a natural father (Hydaspes), an adoptive one (Charicles), and a spiritual one (Calasiris). She has to lose one after another, as she laments, bent over Calasisiris' dead body (7.14.5-6), and meets up with two of them, Hydaspes, of course, but also Charicles, who suddenly appears at her marriage (10.34.3-10.38.4). Here again, the relationship can be compared to a love pattern since Charicles and Calasiris are sent to seek for Charicleia in her lover's place $(10.34 .3 ; 2.22 .4)$. This intrusion of fathers in the general frame of love and adventure novels deserves notice and has been developed later in Story of Apollonius, King of Tyre. The daughters are made, through their submission to their father's power, the instruments of this power, in the very tradition of the couple of Oedipus and Antigone whom Calasiris and Charicleia, wandering in the disguise of beggars, cannot but evoke.

Several conclusions can be drawn from this account and submitted to further discussions. The first one is that rites of passage still influence the Greek representations of education in imperial times, especially aristocratic education that is offered as a cultural pattern of Greek identity. A second conclusion is that Greek novels corroborate inscriptions as far as women's public role is concerned (van Bremen 1996). Women of the elite milieu seem to take a leadership role when they are deprived of kureia and when they are the only representatives of their family. As a third conclusion, the violence of education leads to a traditional form of marriage in which men are the only possessors of freedom of speech, physical activity, power of decision, etc. Young women are the first victims of this education, but young men too are forced to conform themselves to a certain idea of gender roles that may not suit them. Last but not least, marriage, and especially an endogamic marriage, remains one of the major features of Greek culture and one of the last bastions of the Greek city under Roman rule. This must remind us of the importance of social and cultural practices in Greek politeia.

\section{Note}

l I wish to express here a deep gratitude to Saundra Shwartz who has been kind enough to bring some corrections to this paper that I wrote in English and to discuss specific matters. Nevertheless, I assume responsibility for all mistakes that could remain.

\section{References}

André, J.-M. and M.-F. Baslez. 1993. Voyager dans l'antiquité. Paris: Fayard.

Bowie, E.L. 1985. "Theocritus' seventh Idyll, Philetas and Longus.” Classical Quarterly, 25: 67-91.

Duchêne, H. 1992. "Initiation et élément marin en Grèce ancienne." In L'initiation, 2 vols., edited by A. Moreau. Montpellier: Université Paul Valéry, pp. 119-133. 
Gleason, M.W. 1995. Making Men: Sophists and Self-Presentation in Ancient Rome. Princeton: Princeton University Press.

Golden, M. 1990. Children and Childhood in Classical Athens. Baltimore: Johns Hopkins University Press.

Hunter, R.L. 1983. A Study of Daphnis and Chloe. Cambridge: Cambridge University Press.

Hunter, R.L. 1994. "History and historicity in the romance of Chariton." Aufstieg und Niedergang der römischen Welt, II.34.2: 1055-1086.

Konstan, D. 1999. Friendship in the Classical World. Cambridge: Cambridge University Press.

Lalanne, S. 1998. "Récit d'un télos éroticon : réflexions sur le statut des jeunes dans le roman de Chariton d'Aphrodisias." Revue des études grecques, 111.2: 518-550.

Lalanne, S. 2006. Une éducation grecque. Rites de passage et constructions des genres dans le roman grec ancien. Paris: La Découverte. Offers an anthropological reading of the Greek novels related to the historical context of their production.

Lalanne, S. 2007. "Le roman grec, une histoire de genre." In Problèmes du genre en Grèce ancienne, edited by V. Sebillotte Cuchet and N. Ernoult, 185-196. Paris: Publications de la Sorbonne.

Lalanne, S. 2010. "Le chasseur noir, le roman grec et le refus du passage." In Les rites de passage. De la Grèce d'Homère à notre XXI e siècle. Hommage à Arnold Van Gennep et Pierre VidalNaquet. Grenoble: Musée Dauphinois, pp. 111-119.

Loraux, N. 1981, “Le lit, la guerre.” L'Homme 21.1, 1981: 37-67, re-edited in N. Loraux. 1989. Les expériences de Tirésias, Paris: Gallimard.

Loraux, N. 1982. "Mourir devant Troie, tomber pour Athènes: de la gloire du héros à l'idée de cite." In La mort, les morts dans les sociétés anciennes, edited by G. Gnoli and J.-P. Vernant. Cambridge and Paris: Cambridge University Press, pp. 27-43.

Marrou, H.-I. 1981 (1948). Histoire de l'éducation dans l'Antiquité Paris, Seuil. Two volumes (translated by George Lamb and published in one volume in 1956 as A History of Education in Antiquity. London: Sheed and Ward, and in a revised edition in 1982. Madison: University of Wisconsin Press). Remains the major reference on the subject. Has been completed with the two volumes edited by Y.L. Too in 2001, and by J.-M. Pailler and P. Payen in 2004.

Morgan, J.R., ed. 1997. Heliodorus: An Ethiopian Story, trans. Sir Walter Lamb. London: J. M. Dent; Rutland: Dutton.

Morgan, J.R., ed. 2004. Longus, Daphnis and Chloe. Oxford: Aris \& Phillips.

Néraudeau, J.-P. 1979. La jeunesse dans la littérature et les institutions de la Rome républicaine. Paris: Les Belles Lettres.

Pailler, J.-M., and P. Payen, eds. 2004. Que reste-t-il de l'éducation classique? Relire le "Marrou», Histoire de l'éducation dans l'Antiquité. Toulouse: Presses Universitaires du Mirail.

Perry, B. 1967. The Ancient Romances: A Literary-Historical Account of Their Origins. Berkeley and Los Angeles: University of California Press.

Reardon, B.P., ed. 1989. Collected Ancient Greek Novels. Berkeley and Los Angeles: University of California Press.

Robert, L. 1960. "Inscriptions de Lesbos." Revue des études anciennes, 62: 304-305.

Rosen, R.M. and I. Sluiter, eds. 2003. Andreia: Studies in Manliness and Courage in Classical Antiquity. Leiden: Brill. An important step in the study of men's history in Antiquity.

Roussel, P. 1951. "Etude sur le principe de l'ancienneté dans le monde hellénique." Mémoires de l'Institut national de France, Académie des Inscriptions et Belles Lettres, 43: 123-227.

Schmitt Pantel, P. 1994-1995. "Autour d'une anthropologie des sexes. À propos de la femme sans nom d'Ischomaque." Metis, 9-10: 299-305.

Sebillotte Cuchet, V. and N. Ernoult, eds. 2007. Problèmes du genre en Grèce ancienne. Paris: Publications de la Sorbonne. Provides a good survey of the French approach to gender history by actual specialists of historical anthropology. 
Too, Y.L., ed. 2001. Education in Greek and Roman Antiquity. Leiden and Boston: Brill. van Bremen, R 1996. The Limits of Participation: Women and Civic Life in the Greek East in the Hellenistic and Roman Period. Amsterdam: Gieben.

van Gennep, A. 1960 (1909). The Rites of Passage. Chicago: University of Chicago Press. van Nijf, O. 2003. "Athletics, andreia and the askêsis-culture in the Roman East." In Andreia: Studies in Manliness and Courage in Classical Antiquity, edited by R.M. Rosen and I. Sluiter. Leiden: Brill, pp. 263-286.

Vernant, J.-P. 1982. "La belle mort ou le cadavre outragé.” In La mort, les morts dans les sociétés anciennes, edited by G. Gnoli and J.-P. Vernant. Cambridge and Paris: Cambridge University Press, pp. 45-76.

Vernant, J.-P. 1989. “Entre la honte et la gloire: l'identité du jeune spartiate.” In L'individu, la mort, l'amour. Soi-même et l'autre en Grèce ancienne, edited by J.-P. Vernant. Paris: Gallimard, pp. 173-206.

Vernant, J.-P., and P. Vidal-Naquet. 1992. La Grèce ancienne. Tome 3: Rites de passage et transgressions. Paris: Seuil. Collects all relevant articles of these two major specialists of initiation in the Greek world and of structuralist reading of literary texts.

Winkler, J.J. 1981. "Interlude: Reading against the grain. The education of Chloe: Hidden injuries of sex." In The Constraints of Desire: The Anthropology of Sex and Gender in Ancient Greece, edited by J.J. Winkler. New York: Routledge, pp. 101-126. Traces the hints through which Longus builds the character of his heroine.

Zaidman, B. and P. Schmitt Pantel. 2007. "L'historiographie du genre état des lieux." In Problèmes du genre en Grèce ancienne, edited by V. Sebillotte Cuchet and N. Ernoult. Paris: Publications de la Sorbonne, pp. 27-48.

\section{Further Readings}

Calame, C. 1977. Les chaurs de jeunes filles en Grèce archaïque. Rome: Edizioni dell' Ateneo \& Bizzarri, 2 volumes (first volume translated from the French by D. Collins and J. Orion in 1997 as Choruses of Young Women in Ancient Greece. Lanham: Rowman \& Littlefield Publishers). Remains the most brilliant study of girls' initiation. With an updated bibliography in the 2001 edition.

Konstan, D. 1994. Sexual Symmetry: Love in the Ancient Novel and Related Genres. Princeton: Princeton University Press. Provides a witty and accurate analysis of the Greek novels from the point of view of emotions and passions.

Lupi, M. 2000. L'Ordine delle generazioni. Classi di età e costumi matrimoniali nell'antica Sparta. Bari: Edipuglia.

Pironti, G. 2007. Entre ciel et guerre. Figures d'Aphrodite en Grèce ancienne. Liège: Kernos, suppl. 18. Reinhold, M. 1976. "The generation gap in antiquity." In The Conflict of Generations in Ancient Greece and Rome, edited by S. Bertman. Amsterdam: Grüner, pp. 15-54. 